\title{
Determinants of organisational commitment amongst knowledge workers
}

\author{
Lisa Kinnear* \& Margaret Sutherland \\ Graduate School of Business Administration, University of the Witwatersrand, P.O.Box 98, Wits, 2050 South Africa
}

Received June 2000

\begin{abstract}
The knowledge economy and the knowledge worker are a phenomena of the twentieth century. While knowledge-based organisations are reliant on the knowledge of individuals for their success, they can no longer rely on the loyalty of these highly skilled and marketable employees. The main purpose of this study was to gain insight into what determines commitment to an organisation amongst knowledge workers. The data was collected by means of a survey of 104 knowledge workers from the financial services, information technology and science and technology sectors. The data was subjected to inferential and multivariate statistical analysis. The main findings of this research was that knowledge workers reject traditional retention systems in favour of individualism, independence and personal achievement. These findings are integrated into a model which highlights how knowledge workers' needs can be met through retention strategies which focus on freedom to act independently; financial reward and recognition; developmental opportunities; and access to leading edge technology.
\end{abstract}

* Author to whom correspondence should be addressed.

\section{Introduction}

The knowledge era has been described as the economic and social order of the twenty-first century where knowledge is the key resource as opposed to labour, raw materials or capital. Peter Drucker (1994) argues that relationships between employees and employers are consequently transforming since employees own the tools of production through the knowledge they hold.

South African organisations have traditionally focused on the collective relationship of management and labour. However, as South Africa becomes a global player in the international environment, South African companies need to pay attention to the powerful role of the individual knowledge worker.

The old social contract of employee loyalty is on the decline as companies can no longer guarantee job security in the face of pressures resulting from global competitiveness. As a result key employees are becoming more assertive in making their demands on employers or looking elsewhere for employment. Retention of employees who use their knowledge to produce goods or services for companies' profits is becoming an increasingly important challenge faced by organisations world-wide.

For the purposes of this research, knowledge workers are defined as employees who have specialist knowledge and are involved in the activities of research; applied research; development work leading to new products or processes; and consulting based on specialist knowledge.

United Nation statistics (Despres \& Hiltrop, 1995) show an upward trend in the employment of knowledge workers in the United States, Europe and Japan. South Africa is not only competing with these countries in their retention of highly skilled employees, but is currently facing a shortage of specialist skills in professional, technical and management positions (PE Corporate Salary Survey, 1996).
Organisations who rely on knowledge workers in their business need to establish how to gain their commitment so as to retain them. Loss of knowledge workers to an organisation means loss of both tangible and intangible knowledge and potential competitive advantage. This research aims to establish what influences knowledge workers' commitment to an organisation. The results of the research will enable South African employers of knowledge workers to develop practices to retain these valuable employees.

\section{Literature review}

The theories of motivation, job satisfaction and organisational commitment have evolved over time, diverging in perspectives on the organisational environment and the positioning of the individual within that environment. As the world of work has changed, so too has the focus in behavioural scientists' theories applied to management. The general pattern that emerges in the literature reflects a shift in focus from motivation as a method of control, to motivation as a determinant of job satisfaction and more recently to a focus on organisational commitment (Taylor, 1991; Heald, 1995; Wickens, 1995).

While there has been extensive research conducted into organisational commitment, the research has not focused on a specific population, in this case knowledge workers. MaxNeef in Heald (1995) argues that while individual's needs are finite and fixed, satisfiers change over time, depending on the environment and the circumstances. This supports the view that knowledge workers may not necessarily have different needs, but may respond to different satisfiers than those of a past era.

The knowledge worker population is a unique one. Drucker (1989) coined the term 'knowledge worker' and describes these individuals as employees who carry knowledge as a powerful resource which they, rather than the organisation, own. 
Despres \& Hilltrop (1995) characterise knowledge workers as having careers which are external to an organisation through years of education rather than internal through training and career schemes. Their loyalty is therefore to professions, networks and peers rather than to the organisation and its career systems. Knowledge workers tend to work on projects, in teams, dealing with problems and issues as opposed to tasks. As a result knowledge workers are more critical to the long-term success of the organisation than the shortterm efficiencies of the organisation.

It has long been acknowledged by management theorists that human motivation consists of both tangible and intangible needs and are therefore satisfied within a work context by both intrinsic and extrinsic motivators (Heald, 1995; Wickens, 1995). The essential satisfiers of achievement, recognition, work itself, responsibility and advancement (Herzberg, 1959) have been the focus of many of the management practices in hierarchically structured organisations, where they are the primary indicators of success. The literature on knowledge workers indicate that some of the less essential satisfiers proposed by Herzberg, such as personal growth, are now becoming more essential (Simon, 1996; Wickens, 1995; Cook, 1997; Wiig, 1997)

Drucker (1989) claims that in the knowledge worker's value system, business values are subordinate to, and may even be seen as an obstacle to, their performance. Tampoe (1994) believes that the standards of knowledge workers are derived as much from their professional colleagues as from their organisation and that there is room for conflict between corporate needs and individual values. Reichers (1985) suggests that commitment is often to multiple groups within the organisation rather than the organisation itself. In the case of knowledge workers therefore, commitment would be more likely towards professional peers.

Personality variables have been proposed as another dimension affecting organisational commitment (Amold, 1995). In Amold's research, variables of a high work ethic, self-esteem and need for achievement are important determinants of an individual's commitment. However, a high locus of control was found to be negatively related to organisational commitment, indicating that the more employees perceive themselves to be in control of their own destiny, the less likely they are to be committed to an organisation. Knowledge workers therefore need a great deal of autonomy and discretion in their work environment (Handy, 1989; Jooste, 1997) and should be treated as colleagues rather than subordinates to acknowledge their independence (Drucker, 1989; Balkin, Gomez-Meija \& Milkovich, 1990; Koopman, 1991; Peters, 1994). Based on these findings in the literature review, the first research proposition is as follows:

$\mathrm{Pl}$ : The three variables that are perceived to best determine organisational commitment amongst knowledge workers are opportunities for personal development; working with colleagues from whom one can learn; and the freedom to act independently.

Organisations have traditionally attempted to retain employees through the notion of loyalty and a long-term view of employment with the company (Branch, 1998). Benefits such as health care and pension fostered the patriarchal company approach where employees and their families needs were taken care of and they were rewarded for service with the company (Morgan, 1996). Consequently employees became more entrenched in and less employable outside of the organisation (Waterman, Waterman \& Collard, 1994). While some more progressive companies are shifting away from this approach, these benefits remain an expectation of employees. However, loyalty and job security are being replaced with the need for commitment on the part of the employer and employability on the part of the employee (Wickens, 1995). The second research proposition is therefore as follows:

P2: Traditional retention practices such as pension scheme, health care benefit, loyalty, contractual obligation and job security, will not significantly influence knowledge workers' decision to remain with an organisation.

The new world of work is the organisational response to the knowledge economy. Commitment of knowledge workers within this environment needs to be achieved in emphasising the uniqueness of individual value systems rather than generic motivators (Lapin, 1993; Wickens, 1995; Jooste, 1997). The ability of an individual to realise their identity is regarded as the crux of organisational commitment (Bramer \& Winslow, 1994; Heald, 1995). Agarwal \& Ferrat (1997) propose that for employees to be committed in the work environment, a balance needs to be established between personal, professional and organisational identities.

Personal identity represents the individual's ability to realise their values and fulfil their needs external to the work environment (Klimoski \& Hayes, 1980; Bass, 1981; Araki, 1982; Dumaine, 1994; Levering \& Moskowitz, 1998). The knowledge worker's need for personal growth would form part of their personal identity (Cook, 1997; Duffy, 1997). Professional identity reflects the knowledge worker's need for meaningful work and working relationships (Agarwal \& Ferrat, 1997). Knowledge workers have a need to work with and learn from professional colleagues (Dumaine, 1994; Brown \& Duguid, 1996; Cook, 1997; Duffy, 1997). They also require challenging work assignments and access to 'state of the art' technology to realise their professional identity (Mc-Neese Smith, 1996; Wiig, 1997). Organisational identity reflects the need for individuals to define their own role in the organisation, contributing to its purpose and sharing in its success (Agarwal \& Ferrat, 1997). Knowledge workers need both autonomy and discretion in executing their work (Jooste, 1997; Wickens, 1995). They need to share in the financial rewards of the company as a means of recognition of their knowledge, skills and experience (Kanter, 1989; Wickens, 1995; Despres \& Hilltrop, 1995). The third proposition is therefore as follows:

P3: The variables determining organisational commitment amongst knowledge workers can be structured according to the three factors of the knowledge workers' ability to realise their personal, professional and organisational identity.

It has been acknowledged that the perception of job satisfaction would be different across different employee populations (Hulin, Roznowsi \& Hachiya, 1985). Employees from different populations would focus on different factors and would have varying personal or organisational circumstances (Price \& Mueller, 1986). In determining retention strategies therefore, there is an argument for focusing on motivations of 
specific populations, such as knowledge workers, rather than a generic approach. Likewise, sub groups within the knowledge worker population may have different determinants of organisational commitment. Proposition four is therefore as follows:

P4: It is anticipated that the determinants of organisational commitment will differ according to the demographics of age, race, gender, level, years of service and industry type.

\section{Research methodology}

The survey method was selected as a means of gathering data via a questionnaire to establish what determines organisational commitment amongst knowledge workers in the financial services, information technology and science and technology sectors.

\section{Pilot research}

The pilot research phase aimed at confirming that the variables which had emerged from the literature survey were comprehensive and relevant to South African organisations. Six knowledge workers were interviewed in depth to establish factors which would influence their decision to stay with or leave an organisation. These knowledge workers were selected to ensure representation of all three industries being surveyed. Knowledge workers were asked to identify what would attract them to an organisation, retain their commitment to an organisation and cause them to leave an organisation. Responses were probed to clarify interpretation and to determine prioritisation of the factors identified.

Data from these interviews was analysed by coding responses which were similar and subjecting them to frequency counts to determine which factors had the highest priority. These factors were then compared with those identified in the literature review and were combined to form the 45 constructs in the questionnaire.

\section{Questionnaire construction}

The questionnaire followed the recommendations of Leedy (1997) and Pirow (1994). It consisted of three sections. The first section included eight questions to establish the demographic details of the respondents and their organisations. The second section comprised a set of 45 statements indicating factors which influence employees' decision to remain with an organisation. Respondents were required to rate the level of influence these factors would have on their decision to stay with an organisation. A four-point Likert scale was provided, with 'no influence' scoring 1 to 'highly significant influence' scoring 4. Section three included two open-ended questions, enabling respondents to add anything which they felt the questionnaire had not covered, which would influence their decision to remain with an organisation.

The questionnaire was pre-tested and as a result of the feedback, certain questions and instructions were re-worded to improve its clarity.

\section{Population and sample}

The target population comprised all knowledge workers employed in the science and technology, financial services and information technology industries in South Africa. These three industries were chosen because they are highly de. pendant on knowledge workers for their survival and because of the high turnover of knowledge workers within these industries (PE Corporate Salary Survey, 1996). Non-proba. bility sampling was used to select three organisations in each of these industries, representing a cross section of both large and small organisations.

\section{Data collection}

A contact person in each organisation was asked to distribute the questionnaires to a minimum of 30 knowledge workers in their organisation. The cover letter requested that the person use judgement sampling based on the researcher's criteria to determine participants in the study. The criteria included the definition of the knowledge worker, as well as a request to gain a representative spread across age, race and level in the organisation.

\section{Data analysis}

The individual and organisational demographic information as provided in section 1 of the questionnaire was analysed by means of non-parametric statistics to establish whether the sample adequately reflected the knowledge worker population in South Africa

The data collected via the Likert scale in section 2 was subjected to correspondence analysis in order to perform parametric statistical functions (Bendixen \& Sandler, 1995). Data was then subjected to factor analysis, the Kruskal-Wallis and Mann-Whitney $U$ tests to test the four propositions.

\section{Research findings}

A total of 104 questionnaires were analysed out of the 180 questionnaires distributed to the six organisations targeted. The return rate of usable responses was $58 \%$ which was higher than anticipated. The sample adequately reflected the knowledge worker population in South Africa as defined for the purposes of this research. The population is predominantly white males between the ages of 20 and 39 with education levels of bachelors or honours degrees. The split between industries represented was fairly even, with the science and technology industry making up $38 \%$ of the total sample; information technology making up $32 \%$; and financial services making up $30 \%$ of the total.

\section{Rescaling of the data}

Correspondence analysis was used to rescale the ratings on the Likert scale of the 45 statements in the questionnaire from ordinal data to interval data. The principal co-ordinates of the four-point Likert scale on the first axis ranged from +1.010 to -0.422 .

It is evident from Table 1 that the interval scale is slightly different from the assumed numerical values of $1,2,3$ and 4 of the four-point Likert rating scale.

Proposition 1: Variables that best determine organisational commitment

To establish which variables best determine organisational commitment, the 45 variables in the questionnaire were ranked. The means on the rescaled data were calculated for all 
Table 1 Conversion of Likert scale rating

\begin{tabular}{llc}
\hline Likert & Verbal scale & Rescaled \\
\hline 1 & No influence & 1 \\
2 & Little influence & 2.23 \\
3 & Significant influence & 2.96 \\
4 & Highly significant influence & 4 \\
\hline
\end{tabular}

45 statements. Table 2 represents the ten most preferred retention strategies.

Based on the ranked means in Table 2, the variables which have the highest influence on commitment to an organisation can be grouped and summarised as: financial reward and recognition; developmental opportunities; freedom to act independently; and tools and technology. over other developmental needs. The findings do not support the observation that personal growth is increasingly important for the knowledge worker, but rather that development is related to the essential satisfiers of achievement and advancement (Herzberg, 1959).

The finding confirms that knowledge workers require freedom in planning and executing their work and progressive leadership which allows them to do things differently. Knowledge workers need space to act independently so as to apply their unique talents. The learning organisation (Senge, 1990) with its removal of structures which hinder this freedom will help address this need amongst knowledge workers. However, the communal team-based approach promoted by the new organisational dynamic was not found to have a significant influence on knowledge workers' commitment to an organisation. The knowledge worker's need for independence is

Table 2 Ten most preferred retention strategies

\begin{tabular}{llc}
\hline Rank & Statements & Means \\
\hline 1 & A competitive remuneration package & 3.58 \\
2 & Opportunities for development in your area of expertise & 3.51 \\
3 & Incentives linked to performance & 3.5 \\
4 & Challenging work assignments in your area of expertise & 3.5 \\
5 & Freedom to plan and execute work independently & 3.48 \\
6 & Colleagues that you feel you can learn from & 3.37 \\
7 & Growth potential of the industry & 3.35 \\
8 & Access to 'leading edge' technologies and products & 3.34 \\
9 & Progressive leadership which allows you to do things differently & 3.34 \\
10 & Share in the profits of the business & 3.33 \\
\hline
\end{tabular}

The finding confirms that financial reward and recognition is a primary motivator, despite the widely held views in the literature that this is not so. While the highest ranked variable was a competitive remuneration package, this represents the subsistence component of Max-Neef's matrix of needs (Heald, 1995). Financial reward and recognition goes beyond the subsistence dimension, however. Performance-based incentives relates to the individual and competitive nature of the knowledge worker, which appears as a strong theme throughout the top ten variables and is supported in the literature by Cook (1997), Drucker (1989), Duffy (1997) and Jooste (1997). Profit share reflects the need for financial recognition through the form of participation in the business (Heald, 1995; Kanter, 1989).

The finding also introduces technology as an important driver of commitment amongst this particular population. While some of the literature acknowledges technology as an important consideration (McNeese-Smith, 1996; Drucker, 1989), it is not emphasised to the same degree as it is in the findings of this research. This highlights the technology focus of the knowledge worker's job as a motivator which is most likely to be uniquely linked to this population.

The finding indicates that knowledge workers value learning from professional colleagues and development in their specialist area. It supports the view of Drucker (1989) that development of professional expertise tends to take precedence linked to their individualistic and achievement orientation These are the key themes which emerge from the top ten variables.

Proposition 2: Impact of traditional retention factors on knowledge workers

To establish which variables have the least influence on organisational commitment, the bottom ten variables out of the 45 ranked means are recorded in Table 3.

Table 3 Ten least preferred retention strategies

\begin{tabular}{llc}
\hline Rank & Statements & Means \\
\hline 36 & Health care benefit & 2.75 \\
37 & Being able to apply your education directly to your job & 2.74 \\
38 & Clearly structured promotional progress & 2.63 \\
39 & Pension scheme & 2.62 \\
40 & Well-defined job descriptions with clear responsibilities & 2.54 \\
41 & Availability of jobs in the market & 2.43 \\
42 & Time for socialising and relaxation at work & 2.41 \\
43 & $\begin{array}{l}\text { Need for a change } \\
44\end{array}$ & $\begin{array}{l}\text { Encouragement to associate with institutionalised pro- } \\
\text { fessional bodies }\end{array}$ \\
45 & $\begin{array}{l}\text { Contractual obligation due to educational assistance } \\
\text { received from the company }\end{array}$ & 2.14 \\
\hline
\end{tabular}


The variables which have the least impact on commitment of knowledge workers to an organisation can be grouped as the traditional retention factors of health care, pension and contractual obligation; structured jobs and career progression; emphasis on institutionalised professional links; social work environment; and external attractors (that is need for change or availability of jobs in the market).

The finding that traditional retention factors do not significantly influence knowledge workers' decision to remain with an organisation is important. It highlights the rejection by knowledge workers of traditional retention systems, which are still relied on by many organisations. It indicates the importance of identifying alternative retention strategies for this population.

\section{Proposition 3: Factor structure of variables}

To reduce the 45 statements into a smaller number of factors that underly organisational commitment, factor analysis was performed on the rescaled data. A four-factor solution was adopted based on eigenvalues greater than one; the point at which the scree plot alters significantly; and because the factors could be clearly defined and logically interpreted. All factor loadings greater than 0.5 were included in the relevant factor. Cronbach's co-efficient alpha was used to assess the internal reliability of each of the factors. The variables which attributed to the four-factor solution are presented in Tables 4.1 to 4.4. The tables include the co-efficient alpha and mean average for each factor.

Table 4.1 Business ownership

\begin{tabular}{lccc}
\hline $\begin{array}{l}\text { Statement } \\
\text { Involvement in important management and }\end{array}$ & $\begin{array}{c}\text { Factor } \\
\text { loading }\end{array}$ & $\begin{array}{c}\text { Co-efficient } \\
\text { alpha }\end{array}$ & $\begin{array}{c}\text { Factor } \\
\text { average }\end{array}$ \\
$\begin{array}{l}\text { business decisions } \\
\text { Regular contact with senior management and }\end{array}$ & 0.750 & 0.832 & 3.01 \\
leadership of the organisation & & & \\
$\begin{array}{l}\text { Incentives linked to performance } \\
\text { Share in the profits of the business }\end{array}$ & 0.739 & \\
Growth potential of the industry & 0.716 & \\
$\begin{array}{l}\text { Incentives for idea generation } \\
\text { Identification with the business goals of the } \\
\text { organisation }\end{array}$ & 0.601 \\
Being given a lot of responsibility early on & 0.577 \\
\hline
\end{tabular}

Table 4.2 Traditional retention factors

\begin{tabular}{lrcc}
\hline Statement & $\begin{array}{c}\text { Factor } \\
\text { loading }\end{array}$ & $\begin{array}{r}\text { Co-efficient } \\
\text { alpha }\end{array}$ & $\begin{array}{r}\text { Factor } \\
\text { average }\end{array}$ \\
\hline Health care benefit & -0.799 & 0.791 & 2.78 \\
Pension scheme & -0.767 & & \\
Job security & -0.702 & \\
Recognition for qualifications through the & -0.692 & \\
pay system & & \\
Clearly structured promotional progress & -0.675 \\
Recognition for experience through the pay & -0.648 \\
system & & \\
Loyalty to the company & -0.538 \\
\hline
\end{tabular}

Table 4.3 Developmental roles and relationships

\begin{tabular}{|c|c|c|c|}
\hline Statement & $\begin{array}{c}\text { Factor } \\
\text { loading }\end{array}$ & $\begin{array}{c}\begin{array}{c}\text { Co-efficient } \\
\text { alpha }\end{array} \\
\end{array}$ & $\begin{array}{l}\text { Factor } \\
\text { average }\end{array}$ \\
\hline Exposure to experts from your profession & 0.055 & 0.685 & 3.24 \\
\hline Colleagues that you fecl you can learn from & $0.58 \mathrm{I}$ & & \\
\hline $\begin{array}{l}\text { Well-defined job descriptions with clear } \\
\text { responsibilities and accountabilities }\end{array}$ & 0.536 & & \\
\hline A culture of learning and sharing learning & 0.527 & & \\
\hline
\end{tabular}

Table 4.4 Personal needs

\begin{tabular}{lccc}
\hline Statement & $\begin{array}{c}\text { Factor } \\
\text { loading }\end{array}$ & $\begin{array}{c}\text { Co-efficient } \\
\text { alpha }\end{array}$ & $\begin{array}{c}\text { Factor } \\
\text { average }\end{array}$ \\
\hline $\begin{array}{l}\text { Flexibility to work on own terms (e.g.: } \\
\text { work from home; flexi-time) }\end{array}$ & 0.684 & 0.680 & 2.38 \\
Time for personal life outside of work & 0.673 & & \\
Generous leave & 0.666 & & \\
\hline
\end{tabular}

\section{Factor 1: Business ownership}

The statements which load onto this factor are concerned with the knowledge worker's level of involvement in and ownership of the business. Based on this factor solution, business ownership has to do both with sharing in the financial success of the company and in the relationship and involvement with management. The mean average for this factor is 3.01 which suggests that it is of medium significance to knowledge workers as a retention strategy. The mean rankings indicate however, that the more important component of business ownership for the knowledge worker is financial, rather than participation in organisational and management issues.

\section{Factor 2: Traditional retention factors}

The statements which load onto this factor are concerned with traditional determinants of organisational commitment. They include aspects such as loyalty, job security, structured promotional progress, health care and pension. The average of the means for this factor is low at 2.78. This indicates that traditional retention factors can be grouped together and regarded as having little impact on organisational commitment.

\section{Factor 3: Developmental roles and relationships}

The statements are concerned with learning from other professionals as well as clear responsibilities and accountabilities. This factor relates both to the ability to focus on area of expertise through clearly defined roles, the need to associate with people from the same profession and learning as a whole. The average of the means for this factor is relatively high at 3.24 indicating that this is a significant retention factor for knowledge workers. There is some relationship between this factor and the proposed factor of professional identity in so far as it focuses on learning from colleagues and professional experts. However the factor goes beyond the professional domain and reflects the knowledge worker's identity in relation to others.

\section{Factor 4: Personal needs}

The statements which load onto this factor are concerned with the personal needs of the knowledge worker for flexibility 
and free time. The factor reflects elements of the proposed personal identity factor. The average of the means for this factor is the lowest at 2.38. This is interesting as it contradicts the notion from the literature (Levering \& Moskowitz, 1998; Peters, 1994) that individuals are seeking to merge their work and personal lives to achieve a more balanced life.

While this four-factor solution indicates which variables are viewed in the same light by knowledge workers, the fact that only 22 of the 45 statements loaded onto these factors is important. It highlights that less than half of the variables from the questionnaire can be grouped and treated as the same. It can therefore be concluded that the needs of knowledge workers are extremely individual and specific. This supports Wickens' view (1995) that companies need to appeal to unique and individual value systems rather than generic motivators.

\section{Proposition 4: Demographic factors contributing to organisational commitment}

The impact of the demographics of age; years of service; size of the organisation and industry type on retention factors were determined by subjecting the data to a Kruskal-Wallace test. The impact of the gender demographic was determined by subjecting the data to the Mann-Whitney $U$ test. These tests determined whether the medians of these categories were different for each variable. Out of a possibility of 315 differences, a total of only 34 differences between demographic groups were found. The low number of differentials indicate that the determinants of organisational commitment are generic and do not differ according to demographics. This is an important finding since it means that companies need to view retention strategies in terms of the knowledge worker population and in terms of the needs of individuals, rather than the needs of specific groups within that population. Where differences were found within demographic groups, they are represented in Table 5.

Table 5 Demographic differences

\begin{tabular}{lc}
\hline Demographic & $\begin{array}{c}\text { Number of differences in } \\
\text { medians out of } 45\end{array}$ \\
\hline Age & 6 \\
Gender & 2 \\
Years of service & 7 \\
Size of organisation & 8 \\
Industry type & 11 \\
\hline
\end{tabular}

\section{Conclusion}

The main findings of the research can be summarised in a model which takes into account the most important retention practices identified by knowledge workers. Since little research has been conducted into the links between commitment and the knowledge worker population this model aims at addressing this gap (see Figure 1).

The model identifies the four most important factors in retaining knowledge workers as: freedom to act independently: financia! reward and recognition; developmental opportunities; and access to leading edge technologies. The broader

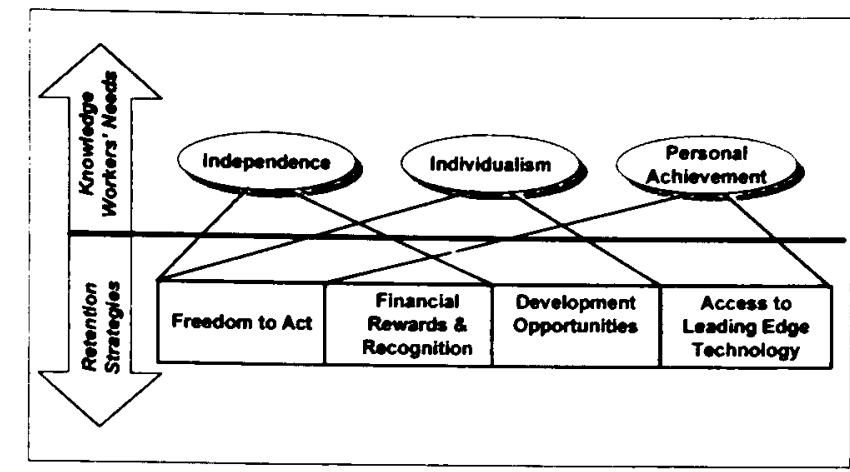

Figure 1 Model of retention strategies to promote knowledge worker commitment

needs of knowledge workers which have been strongly identified in the findings of this research relate to individualism, independence and personal achievement. Individualism highlights the knowledge worker's focus on individual gain as opposed to collectivism. Independence is closely related in that it reflects the knowledge worker's desire to operate in an environment free from constraints to satisfy their individual needs. Similarly, the achievement orientation of knowledge workers is based on individual success. The model indicates that these needs are satisfied through the four retention strategies.

The findings of this research provides employers with new information regarding knowledge worker's needs. It highlights knowledge worker's rejection of traditional retention systems in favour of practices which promote individualism, independence and personal achievement. This study has begun to develop an understanding of the drivers of commitment amongst knowledge workers; unique and increasingly important contributors to the knowledge-based economy. Organisations employing knowledge workers need to review their management practices to create the work environment which encourages these employees to remain with the organisation should they wish to retain their knowledge-based advantage over their competitors.

\section{References}

Agarwal, R. \& Ferratt, T. 1997. Effective and innovative practices for recruiting. SIM International Network, December.

Araki, C. T. 1982. Leadership study in Hawaii - how characteristics of principals affect the schools, VASSP Bulietin, 66(2): 88-96.

Arnold. C. 1995. Some antecedents of employee commitment and their influence on job performance: a multi foci study. South African Journal of Business. Management. 26(4): 25-135

Balkin. D. Gomez-Meija. L. \& Milkovich. G. 1990. Rethinking rewards for technical employees. Organisational Dynamics. 18(4): 62-75.

Bass, B.M. 1981. Stogdill's handbook of leadership. New York: The Free Press

Bendixen. M.T. \& Sandler. M. 1995. Converting verbal scales to interval scales using correspondence analy sis. Management Dynamics: Contemporan Research. $4(1): 31-49$.

Branch. S. 1998. You hired 'em. But can you keep 'em?. Fortune. 9 $101-103$

Bramer. W. \& Winslow. C. 1994. Futurew ork. New York: The Free Press.

Brown. J.S. \& Duguid, P. 1996. Organisational learning and communities-of-practice. In Cohen, M.D. \& Sproull, L.S. eds. 
Organisational learning. California: Sage Publications.

Cook, J. 1997. Knowledge management: enhancing individual learning, Leveraging Knowledge for Business Performance, Proceedings of the First South African Knowledge Management Conference. Johannesburg: University of the Witwatersrand, pp 53-64.

Despres, C. \& Hiltrop, J.M. 1995. Human resource management in the knowledge age: current practice and perspectives on the future, Employee Relations, 17(1): 9-23.

Drucker, P. 1989. The new realities. Ist ed. Oxford: Heinemann Professional Publishing Ltd.

Drucker, P. 1994. Age of social transformation, The Atlantic Monthly, November: 53-80.

Duffy N, 1997. The knowledge age and its significance for business, Leveraging Knowledge for Business Performance, Proceedings of the First South African Knowledge Management Conference. Johannesburg: University of the Witwatersrand, pp. 19-40.

Dumaine, B. 1994. Why do we work?, Fortune, 130(13): 130-135.

Handy, C. 1989. The age of unreason. London: Arrow Books Ltd.

Heald, G. 1995. Deep-rooted conflict and the industrial relations interface in South Africa, South African Journal of Labour Relations: $23-60$

Herzberg, F. 1959. The motivation to work. New York: Wiley

Hulin, C.L., Roznowsi, M. \& Hachiya, D. 1985. Alternative opportunities and withdrawal decisions: empirical and theoretical discrepancies and an integration, Psychological Bulletin, 97: 233250.

Jooste, A. 1997. New strategic questions for the knowledge age, Leveraging knowledge for business performance, Proceedings of the First South African Knowledge Management Conference, Johannesburg: University of the Witwatersrand, pp. 83-105.

Kanter, R.M. 1989. When giants learn to dance. London: Unwin.

Klimoski, R.J. \& Hayes, N.J. 1980. Leadership behaviour in subordinate motivation, Personnel Psychology, 33(3): 543-555.

Koopman, P.L. 1991. Between control and commitment: management and change as the art of balancing, Leadership and OD Journal, 12(5): 3-7.

Lapin, D. 1993. Global ethics, Concepts, 3(1).

Leedy, P. 1997. Practical research: planning and design. New Jersey: Merrill.
Levering, R. \& Moskowitz, M. 1998. The 100 best companies to work for, Fortune, December: 26-35.

McNeese-Smith, R.N. 1996. Increasing employee productivity, job satisfaction, and organisational commitment, Hospital and Health Services Administration, 41(2): 160-175

Morgan, G. 1996. Images of organisations. California: Thousand Oaks: Sage Publications

PE Corporate Services. 1996. The South African salary survey in htman resources practitioners handbook. Johannesburg: PE Corporate Services.

Peters, T. 1994. The Tom Peters seminar: crazy times call for crazy organisations. London: Macmillan

Pirow, P. 1994. A guide for management research. South Africa: Woodacres Publishers.

Price, J. \& Mueller, G. 1986. Absenteeism and turnover of hospital employees. Greenwich: JAI Press

Reichers, A.E. 1985. A review and reconceptualisation of organisational commitment, Academy of Management Review, 20(3): 465476.

Senge, P. 1990. The fifth discipline. New York: Doubleday.

Simon, H.A. 1996. Bounded rationality and organisational learning. In Cohen, M.D. \& Sproull, L.S. eds. Organisational learning. California: Sage Publications.

Tampoe, M. 1994. Knowledge workers: the new management challenge, Professional Manager, November: 12-13.

Taylor, F.W. 1991. The principles of scientific management. New York: W.W. Norton

Waterman, R.H., Waterman, J.A. \& Collard, B. 1994. Toward a career resilient workforce, Harvard Business Review, July-August 87-95.

Wickens, P. 1995. The ascendant organisation. Basingstoke. Macmillan Press Ltd.

Wiig, K M, 1997. Global trends and perspectives on knowledge management, Leveraging knowledge for business performance, Proceedings of the First South African Knowledge Management Conference, Johannesburg. University of the Witwatersrand, pp. $1-16$. 